\title{
Political Stubbornness and Online Local Budget Transparency in Croatia ${ }^{* 1}$
}

\author{
Katarina Ott², Velibor Mačkić $\dot{c}^{3}$, Mihaela Bronic ${ }^{4}$
}

\begin{abstract}
Online local budget transparency (OLBT) has been recognized as an important feature of good governance. Accordingly, in this paper, OLBT is measured in all 128 cities and a sample of 100 municipalities in Croatia using several key local budget documents published on local government websites. Using a fixed effect Poisson panel model covering the 2013-2017 period, it is shown that along with residents' income and fiscal capacity of local governments, political ideology and political competition determine the level of OLBT. This paper contributes to the growing body of budget transparency literature by establishing the importance of political factors as determinants of OLBT in this former socialist, fiscally centralized EU member state and reveals the curious stubbornness of the citizens who consistently vote for non-transparent politicians. The main finding is that political factors (political ideology and political competition) matters in determining $O L B T$, resulting in suboptimal equilibrium of local governments with low levels of OLBT. The local incumbent concludes that OLBT is not a high priority and that his/her constituency will not hold it against him/her. In this environment such a conclusion stands owing to the fact that voters who are
\end{abstract}

* Received: 19-06-2019; accepted: 02-12-2019

1 This work was supported by the Croatian Science Foundation [grant IP-2014-09-3008].

2 Professor, Senior Research Advisor, Institute of Public Finance, Smičiklasova 21, 10000 Zagreb, Croatia. Scientific affiliation: public sector economics. Phone: +38514886444.E-mail: kott@ ijf.hr. ORCiD: 0000-0003-2242-4181. Website: http://www.ijf.hr/eng/employees/researchers/7/ katarina-ott-phd/1494/ (corresponding author).

3 Assistant Professor, Faculty of Economics and Business, University of Zagreb, Trg J. F. Kennedyja 6, 10000 Zagreb, Croatia. Scientific affiliation: competitiveness analysis, new political economy, political cycles. Phone: +38512383201. E-mail: vmackic@efzg.hr. ORCiD: 0000-0002-32008571. Website: http://www.efzg.unizg.hr/departments/economic-theory/faculty-2831/velibormackic-phd/22082.

4 Senior Research Associate, Institute of Public Finance, Smičiklasova 21, 10000 Zagreb, Croatia. Scientific affiliation: fiscal decentralization and development, tax system, budget transparency. Phone: +38514886444.E-mail: mihaela.bronic@ijf.hr.ORCiD:0000-00020863-2040. Website: http://www.ijf.hr/eng/employees/researchers/7/mihaela-bronic-phd/150/. 
stubborn in their voting patterns refuse to change the incumbent who created nontransparency.

Key words: online budget transparency, local government, Croatia, political economy, panel data model

JEL classification: $H 11, H 70$

\section{Introduction}

Budget transparency (BT) and public participation are crucial for good governance (e.g., Lowatcharin and Menifield, 2015). A transparent budget can be properly analyzed, and its implementation can be easily monitored, enabling citizens to participate (meaningfully) in improving the efficiency and effectiveness of public policies, holding incumbents accountable for their electoral promises, and increasing citizens' trust in government (e.g., Piotrowski and Van Ryzin, 2007; Ríos, Benito, \& Bastida, 2017). Although there are also some arguments against too much BT (see Kopits and Craig, 1998), BT has been encouraged or recommended by numerous international organizations (e.g., OECD, 2002).

Most existing research has focused on BT at the central government level (e.g., Ríos et al., 2013). However, one would expect the citizens to be more interested in local government expenditures, such as how much a local public transport system would cost or what could happen with a local playground.

The development of tools for disclosing financial information, enabled by information and communications technologies (ICT), has led to improvements in BT and accountability (Puron-Cid and Bolívar, 2017), and governments are increasingly publishing budget information online (Corella, 2011) using websites to inform citizens and/or for attempt to hear their voice. ${ }^{5}$ Because of these changes, there is a growing interest focused on the determinants of online local fiscal/budget transparency (OLF/ BT) (e.g., Lowatcharin and Menifield, 2015; Sedmihradská, 2015; Birskyte, 2018; Chen \& Han, 2019). Unfortunately, so far, this trend has largely circumvented fiscally centralized post-socialist countries, such as Croatia. Possible explanations for the lack of interest in OLF/BT can be grouped into institutional design and citizens' attitude. Due to institutional settings, local government units (LGUs) in fiscally centralized post-socialist countries provide fewer public goods compared to their peers in fiscally decentralized countries. On the other side, citizens' themselves neglect their role in the budgetary process because they usually see public money as both "everybody's and nobody's" and think that there is no point in engaging into budgetary process (Ott and Bronić, 2015).

\footnotetext{
5 The internationally comparable Open Budget Index recently also adopted online availability as the minimum necessary condition for determining the public availability of a key budget document International Budget Partnership (IBP) (2018).
} 
But, due to importance of this topic, still since 2013 OLBT in Croatia is measured by the number of key local budget documents (executive budget proposal, citizens' guide and enacted budget) issued on time on local government websites (Ott et al., 2017). This paper contributes to the empirical assessment of OLF/BT by analyzing the importance of a set of political variables in Croatia and noting that citizens stubbornly vote for nontransparent politicians. The paper investigates two hypotheses. Firstly, that there is a negative and statistically significant relationship between a right-wing political incumbent and the level of OLBT. Secondly, that there is a positive and statistically significant relationship between political competition and the level of OLBT.

The paper is organized as follows. First, we present literature review regarding definition and determinants of OLF/BT and then, we present the methodology, empirical data and analysis, results and conclusions.

\section{Literature review}

\subsection{Definition/measurement of OLF/BT}

The first and probably the largest problem in the analysis of the determinants of OLF/BT most likely arises from the fact that there is no unique measure of OLF/ BT, with authors defining and measuring it differently. Some authors argue that fiscal transparency (FT) "is a complex phenomenon to be measured by single variable or indicator" (Puron-Cid and Bolívar, 2017: 4) and that results, to some degree, always depend on the context in which the research is performed (e.g. Muñoz et al., 2016). Therefore, it is not easy to compare different results or determine whether the results could be valid for all or numerous LGUs in different countries. Several questions also arise as follows: should one focus on fiscal and/or budget transparency, online and/or hardcopy transparency, or mandatory and/or voluntary transparency?

Most studies in the literature focus on FT (e.g. Esteller-Moré and Otero, 2012), which is a broader concept than BT, although many authors use these concepts synonymously. ${ }^{6}$ Other authors focus on even broader concepts, including corporate and social planning, decision making, policy information and/or policy outcome

\footnotetext{
${ }^{6}$ For example, OECD (2002: 7), defines BT as "the full disclosure of all relevant fiscal information in a timely and systematic manner", which rather resembles what a definition of FT should be. Kopits and Craig (1998: 1) define FT as "openness toward the public at large about government structure and functions, fiscal policy intentions, public sector accounts, and projections. It involves ready access to reliable, comprehensive, timely, understandable, and internationally comparable information on government activities - whether undertaken inside or outside the government sector - so that the electorate and financial markets can accurately assess the government's financial position and the true costs and benefits of government activities, including their present and future economic and social implications."
} 
transparency (e.g., del Sol, 2013; Grimmelikhuijsen and Welch, 2012). Our research focuses only on budgets and budget transparency, similar to the research of the International Budget Partnership (IBP) (2018) and World Bank (2015). ${ }^{7}$

We have focused our research only on online local budget transparency owing to the fact that numerous authors focus only on OLF/BT (e.g. Esteller-Moré and Otero, 2012; Gandía and Archidona, 2008; García-Tabuyo et al., 2016; Gesuele and Metallo, 2017; Lowatcharin and Menifield, 2015; Pina et al., 2010; Serrano-Cinca et al., 2008; Styles and Tennyson, 2007; Tavares and da Cruz, 2014; Sedmihradská, 2015; Birskyte, 2018). However, there are some authors who analyze both online and hardcopy formats of information (e.g., Guillamón et al., 2011; Laswad et al., 2005), but some scholars pinpoint the fact that the determinants of each format vary and that this should be considered (see Muñoz et al., 2016).

Finally, Guillamón et al. (2011), del Sol (2013), Araujo and Tejedo-Romero (2016), and Araujo and Tejedo-Romero (2017) analyze both mandatory and voluntary transparency. Some authors distinguish between mandatory and voluntary transparency (e.g. Gandía et al., 2016; Gesuele and Metallo, 2017), while only a few authors focus entirely on voluntary disclosure (e.g., Laswad et al., 2005; SerranoCinca et al., 2008). This paper focuses on both mandatory and voluntary OLBT, defined as the possibility for citizens to obtain complete, accurate, and timely information presented in an understandable form about an LGU's budgets from its website (Ott et al., 2017). However, similar to da Cruz et al. (2016), this paper analyzes only the timely availability of documents, assuming that the disclosed information is complete, accurate and presented in an understandable form.

\subsection{Explanatory theories of budget transparency}

Numerous theories/hypotheses have been used to explain the differences in OLF/ BT (principal-agent, neo-institutional, stewardship, fiscal illusion, legitimacy, ruleof law theory, and bureaucratic behavior model); however, for this work, principalagent, legitimacy and rule-of-law theories are the most useful.

Principal-agent theory argues that the problem between a principal (citizens) and agent (politician) arises when a politician (better informed than citizens) puts his/her own interests before the contrary interests of the citizens whom s/he represents (e.g., Ferejohn, 1986). A politician's interests might include rents, such as re-election, the advancement of his/her political career, and the increase of his/her income (Zimmerman, 1977). Ferejohn (1986) notes that the politician chooses how to make his actions evident to the principal and assumes that the

\footnotetext{
7 The World Bank (2015: 1) defines BT as "the extent and ease with which citizens can access information about and provide feedback on government revenues, allocations, and expenditures". A similar view has been described by the International Budget Partnership (IBP) (2018).
} 
politician's compensation is derived in the form of rents that are proportional to the scale of government. Citizens are also self-interested, wanting to know what agents are doing with their money, and thus under the threat of being replaced, a politician is incentivized to choose a level of transparency above zero, leading to larger budgets. Similarly, to the principal-agent theory second generation of fiscal federalism models explain principals' motives assuming that politicians have goals that often diverge from maximizing citizens welfare and thus elections could allow citizens to influence their destiny by throwing bad politicians out. That threat of being thrown out of office incentivizes politicians to make decisions that honor citizens rights (Weingast, 2009). Furthermore, (Ferejohn, 1999) also argues that left-wing governments, wanting a larger public sector, are expected to implement even greater levels of transparency. Lassen (2000) notes that, in accordance with principal-agent theory, voters prefer more public goods and larger budgets when transparency increases.

Legitimacy theory claims that if an LGU's legitimacy is threatened, the LGU will disclose its information hoping that this will increase the LGU's legitimacy and the reputation of local public officials (e.g., Araujo and Tejedo-Romero, 2016; Hoffman, 2001). Alternatively, it could be argued that offering an image of good governance, as a response to external pressure is a way to secure the legitimacy of the LGU (Pina et al., 2010). Incumbents in LGUs with higher budgetary revenues might be more concerned about losing their positions and, consequently, have more interest in proving their efficient management by voluntarily disseminating information (Muñoz et al., 2016).

Rule-of-law theory argues that all government units must act in accordance with and within the limits of the law. It is further argued that the law should govern a nation (government) and not the arbitrary decisions of individual government officials (IAS Score, 2018). Accordingly, it is expected that if the publication of a key budget document is stipulated by law, more LGUs will publish it.

\subsection{Development of hypotheses}

The dominant drivers of OLF/BT have still not been identified, although different authors have used numerous socio-demographic, fiscal, and political variables (please see the remaining part of the section for these conclusions). The most commonly used socio-demographic variables are number/density of population, residents' wealth (income), and other characteristics of population, such as age, education, gender, unemployment, and access to the internet. Usually, the used fiscal variables are measures of a LGUs' wealth, debt, surplus/deficit, intergovernmental transfers, and tax revenues. Regarding political variables, authors use the ideology of the executive/legislative body in LGUs, different measures of political competition, and characteristics of a political leader (tenure, age, gender, etc.). 
OLF/BT research mostly focuses on fiscally decentralized countries and rarely on fiscally centralized countries. Although the results are mixed, the following variables emerge as the most likely determinants: residents' income per capita (p.c.), LGUs' wealth (fiscal capacity) ${ }^{8}$, access to the internet, political ideology, political competition, and population (see Stanić, 2018). Thus, by controlling for four socio-demographic and fiscal variables which will be explained under the methodology section (population, residents' income per capita, LGU's fiscal capacity, internet access), this work focuses on two political variables (ideology and competition), establishing their importance and effect on OLBT. Accordingly, two following hypotheses are developed.

\subsubsection{Political ideology}

It is argued that both left- and right-wing parties promote BT and that alteration of power motivates BT, as all parties want to ensure that they will have access to information should they be voted out of power (Wehner and de Renzio, 2013). In contrast, Gesuele and Metallo (2017) argue that the ruling party's political ideology may support a different e-government style and differently influence OLF/BT. Some other authors argue that left-wing parties are more transparent because they are more likely to expand public services and face greater transparency requirements from citizens (Caamaño-Alegre et al., 2013; Guillamón et al., 2011). del Sol (2013) also stressed that left-wing governments might be more sensitive to the need to provide BT. It is argued that according to both principal-agent and legitimacy theory, it is expected that LGUs that provide more public services publish more budget documents online.

Most authors find political ideology insignificant for OLF/BT (e.g., Esteller-Moré and Otero, 2012; García-Tabuyo et al., 2016), while Gandía et al. (2016) find that left-wing governments are more transparent. Accordingly, the following hypothesis is advanced:

H1. There is a negative and statistically significant relationship between a rightwing political incumbent and the level of OLBT.

\subsubsection{Political competition}

Several authors have found that different measures of political competition encourage incumbents to be more responsive to the electorate and offer more OLF/ BT (e.g., Araujo and Tejedo-Romero, 2016; Esteller-Moré and Otero, 2012; Gandía and Archidona, 2008), while others have found political competition insignificant

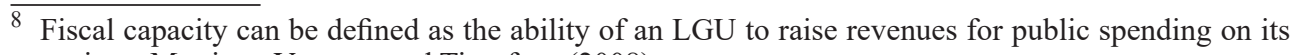
territory Martinez-Vazquez and Timofeev (2008). 
(Araujo and Tejedo-Romero, 2017; García-Tabuyo et al., 2016) or negatively correlated with OLF/BT (Laswad et al., 2005; Serrano-Cinca et al., 2008; Tavares and da Cruz, 2014). On the one hand, Piotrowski and Van Ryzin (2007) suggest that the voter turnout levels can be regarded as indicators of citizen involvement and commitment to participate in political matters, thus positively affecting OLF/ BT. On the other hand Birskyte (2018) argues that higher local turnout does not necessary mean that pro-reform officials are elected, and that this is especially true when local elites are proficient in securing local votes for themselves and Araujo and Tejedo-Romero (2017) argue that lower levels of voter turnout may be incentives for incumbents to increase transparency.

Three measures of political competition (voter turnout, winning margin, and a Herfindahl-Hirschman-based measure of partisan fragmentation) are investigated. Some authors analyzing voter turnout find this variable insignificant (SerranoCinca et al., 2008; Tavares and da Cruz, 2014), while García-Tabuyo et al. (2016) obtained negative (for mandatory disclosure) and insignificant results (for voluntary disclosure). Birskyte(2018) again analyzing 60 Lithuanian municipalities reports that turnout at local election is negatively related to budget transparency. EstellerMoré and Otero (2012) report that only in large municipalities (with more than 5,000 inhabitants) greater voter turnout is associated with higher OLF/BT. Da Cruz et al. (2016) report that higher margin of victory (i.e. lower political competition) negatively affects OLF/BT. García and García (2008) report that the HerfindahlHirschman-based measure of partisan fragmentation positively affects OLF/BT. Assuming that all three measures of political competition positively affect OLF/BT results, the following hypothesis is advanced:

$\mathrm{H} 2$. There is a positive and statistically significant relationship between political competition and the level of OLBT.

\section{Methodology}

The dependent variable (OLBT) is a count data variable ranging from 0 to 3 . For each examined year, the variable measures if a LGU published on its website the executive budget proposal, the enacted budget, and the citizens' guide. If all three documents are published, then OLBT is equal to 3 for the respective LGU. The OLBT has a Poisson distribution, and the resulting model is a fixed effects panel data model. The following logic was used with respect to the fixed effect model. The paper was concerned with the fixed effects themselves (e.g. political ideology of the local incumbent) and thus the aim was to place interpretation on exactly this as the possible explanation of low level of OLBT. Additionally, one could reasonably expect that fixed effects (e.g. ideology) have a relationship with other right-hand side variables (e.g. income per capita, winning margin, etc.). Since 
there are no strict rules regarding when deciding whether to use fixed or random effects, empirical research rests on several econometric tests. The majority of papers uses Hausman (1978) test, but by using this test they neglect some serious problems that come with the test (e.g. the test relies on iid error terms and in panel data this is rarely the case, it cannot be used with clustered or robust standard errors, it cannot include time-invariant variables, it is a chi-squared distributed variable and yet it can be negative, etc.). In order to address these problems, the paper used Mundlak Alternative as the best available test. Mundlak (1978) argues that if there is any correlation between the unit fixed effects and the covariates then the fixed effects model should be favoured over the random effects model. This was the rationale in this paper, when deciding on the appropriate model (fixed versus random effect). Mundlak (1978) suggests modelling the unit-specific effects as:

$$
\begin{aligned}
& \alpha_{i}=\bar{x}_{i} \theta+v_{i} \\
& E\left(\alpha_{i} \mid \bar{x}_{i}\right)=\bar{x}_{i} \theta
\end{aligned}
$$

If $\theta=0$ then there is no correlation between $\alpha_{i}$ and $x_{i}$. Results of the diagnostic tests are provided in the Appendix 2.

Furthermore, baseline Poisson regression equation with robust variance estimates is used:

$$
O L B T_{i t}=\alpha_{0}+\beta_{1} I N C_{i t}+\beta_{2} F C_{i t}+\beta_{3} R I G H T_{i t}+\beta_{4} W M_{i t}+u_{i t}
$$

where $i$ denotes local unit and $t$ time, $\alpha_{0}$ indicates a constant, and $\beta_{i}, i=1,2,3,4$ indicates the estimated coefficients of independent variables. Independent variables are: political ideology of right-wing parties $(R I G H T)$ and winning margin $(W M)$. Control variables residents' income per capita $(I N C)$ and fiscal capacity per capita (FC) have one-time lag, i.e., the OLBT in 2013 is explained by the 2012 INC. Although the OLBT variable is named e.g. OLBT 2013 because we are looking for the 2013 budget proposal, the 2013 enacted budget and the 2013 citizens' guide these documents should have been published in 2012, thus we are using onetime lag for all variables (except political). All political variables (ideology and competition) stem from the local elections held in 2009 (determining data for 2013) and 2013 (determining data for the 2014-2017 period). State and local elections are held every four years in Croatia. Since the local elections are always carried out in May, their effect on the examined publication of budget documents is shown only in the following year (the fiscal year in Croatia starts on January 1). Detailed description of independent variables is provided in Table 1 under Section 4.2.

Together with the baseline model, additional models are estimated that differ from the baseline model in the sense that they do not include RIGHT, which is 
substituted with other ideological variables ( $L E F T$ - political ideology of left-wing party and $L I B E R A L$ - political ideology of liberal party) or an interaction variable (RFCRIGHT - the level of fiscal capacity in the richer LGUs with a right-wing incumbent).

\section{Empirical controls}

Fiscal control variable. Adequate fiscal resources are critical to enable LGUs to promote fiscal transparency online, and in that sense higher LGUs wealth enable LGUs to recruit better ICT equipment and skilled labor (Chen \& Han, 2019). Attempting to determine whether an LGU's wealth has any impact on OLF/BT, authors have used different proxies e.g. own per capita revenues (Gandía and Archidona, 2008; Laswad, Fisher, \& Oyelere, 2005; Chen \& Han, 2019; Gandía, Marrahí, \& Huguet, 2016) or budget/tax revenues per capita (Guillamón, Bastida, \& Benito, 2011; Ma \& Wu, 2011). Laswad et al. (2005) argued that LGUs with better fiscal conditions usually provide more budget information. Laswad et al. (2005) and Guillamón et al. (2011) find a positive relationship between LGUs wealth and OLF/BT, while others find this variable insignificant in all or only some models (e.g., Gandía and Archidona, 2008; Ma \& Wu, 2011). Since all Croatian LGUs have relatively own per capita revenues, and negligible tax autonomy, i.e. they can autonomy decide about only one tax (public land use tax) and similar applies for non-tax revenues which usually earmarked we decided to use a measure of fiscal capacity as a proxy for LGU's wealth. Actually Laswad et al. (2005) also use as a proxy for LGUs wealth own revenue per capita (measured as general revenues other than intergovernmental transfers) which is very similar to our measure of fiscal capacity. Fiscal capacity in this work is measured by an LGU's per capita current (operating) revenues minus grants. It is expected that LGU's fiscal capacity enhances its level of OLBT.

Socio-demographic control variables. We employ residents' income, population and internet access as control variables. According to Piotrowski and Van Ryzin (2007) and Styles and Tennyson (2007), residents with higher incomes have more access to and experience with the internet and, thus, demand more OLF/BT. As several authors have shown that residents' per capita income is an important determinant of OLF/ BT (e.g., Lowatcharin and Menifield, 2015; Styles and Tennyson, 2007), it is used as a control variable. Mentioned authors find a positive impact of residents' per capita income on OLF/BT; therefore, it is expected that higher residents' income per capita is associated with higher the level of OLBT. Most authors argue that larger populations have larger budgets, more access to the internet and the ability to demand greater OLF/BT (e.g., García-Tabuyo et al., 2016); thus, this variable is used as a control variable. Larger cities usually have higher budgets for IT and larger administrative staffs, enabling them to achieve higher levels of OLF/BT (e.g., Caamaño-Alegre et al., 2013). Serrano-Cinca et al. (2008), Styles and Tennyson (2007) and Gesuele 
and Metallo (2017) find a positive and statistically significant relationship between OLF/BT and the number of inhabitants. However, Esteller-Moré and Otero (2012) find a nonlinear relationship (in small municipalities, the relationship is negative, while it becomes positive for larger populations - arguing that this might reflect the greater capabilities of very big municipalities to fulfil their legal obligations), while García-Tabuyo et al. (2016) and Gandía and Archidona (2008) find population to be insignificant. In Croatia, most LGUs experience depopulation, and thus it is excepted that higher population size is associated with lower level of OLBT. Araujo and Tejedo-Romero (2017), among several other authors, argue that there is a positive relationship between internet access and the demand for OLF/BT. As the focus of this work is on the internet availability of budget documents, and several authors report that internet availability positively affects OLF/BT (e.g. Lowatcharin and Menifield, 2015), internet access is included as a control variable. However, it should be noted that García-Tabuyo et al. (2016) reported a positive effect of internet access on mandatory disclosures and a negative effect on voluntary disclosures. Still it is expected that access to the internet enhances the level of OLBT.

\section{Empirical data and analysis}

\subsection{Local governments in Croatia}

Croatia is divided into 20 counties (regional level), 128 cities and 428 municipalities (local level). ${ }^{9}$ LGUs' obligations to publish their enacted budgets and midyear and year-end budget reports online is regulated by the Budget Act (2012) and the Act on the Right of Access to Information (2013), while the recommendation for publishing executive budget proposals and citizens' guides online can be found in the Ministry of Finance (2012) Recommendation. However, there are no sanctions for LGUs that do not fulfill these legal requirements or recommendations. In this work, the online publication of one mandatory document (enacted budget) and two recommended (voluntary) documents (the executive budget proposal and citizens' guide) are investigated because, for the 2013-2014 period, we do not have data about the publication of relevant midyear and year-end budget reports.

\subsection{Sample, independent and dependent variables}

The sample includes all Croatian cities (128) and a random sample of 100 municipalities. ${ }^{10}$ To confirm or reject the stated hypothesis, the independent variables

\footnotetext{
$\overline{9}$ As the capital, Zagreb has a special status as both a city and county. In this work, Zagreb is classified as a city.

${ }^{10}$ For more details about the selected sample, see (Ott et al., 2017). Counties were excluded in this article due to the small variability in their levels of OLBT, while the number of 100 municipalities is
} 
are collected and classified into the following three groups: control, political ideology and political competition variables as shown in Table 1.

Table 1: Definition of variables

\begin{tabular}{|c|c|c|}
\hline Variable & Description & Source \\
\hline \multicolumn{3}{|c|}{ Independent, control } \\
\hline$P O P$ & $\begin{array}{l}\text { a logarithm of the population estimates for the } \\
\text { municipality/city (2012-2016) }\end{array}$ & $\begin{array}{l}\text { Croatian Bureau of Statistics } \\
\text { (CBS) (2017) }\end{array}$ \\
\hline$I N C$ & $\begin{array}{l}\text { a logarithm of the average residents' income per } \\
\text { capita (2012-2016) }\end{array}$ & $\begin{array}{l}\text { (Croatian Bureau of Statistics } \\
\text { (CBS), 2017; Ministry of } \\
\text { Regional Development and EU } \\
\text { Funds 2017) }\end{array}$ \\
\hline$F C$ & $\begin{array}{l}\text { a logarithm of annual fiscal capacity per capita } \\
\text { calculated as operating revenues minus all } \\
\text { grants (after the changes in the personal income } \\
\text { tax system in } 2015 \text { and 2016)* }\end{array}$ & $\begin{array}{l}\text { (Croatian Bureau of Statistics } \\
\text { (CBS), 2017; Ministry of Finance } \\
\text { 2017) }\end{array}$ \\
\hline INTERNET & $\begin{array}{l}\text { the percentage of households with broadband } \\
\text { internet access and data transmission speeds of } \\
2 \text { Mbit and more (2012-2016) }\end{array}$ & $\begin{array}{l}\text { Croatian Regulatory Authority for } \\
\text { Network Industries (2018) }\end{array}$ \\
\hline \multicolumn{3}{|c|}{ Independent, political ideology } \\
\hline RIGHT & $\begin{array}{l}\text { dummy variable denoting the political ideology } \\
\text { of right-wing parties, with a value of } 1 \text { if } \\
\text { the incumbent is a member of the Croatian } \\
\text { Democratic Union (HDZ), Croatian Peasant } \\
\text { Party (HSS) or a coalition in which these parties } \\
\text { participate (2009 and } 2013 \text { local elections) }\end{array}$ & $\begin{array}{l}\text { State Electoral Commission } \\
\text { (2009), State Electoral } \\
\text { Commission (2013) }\end{array}$ \\
\hline$L E F T$ & $\begin{array}{l}\text { dummy variable denoting the political } \\
\text { ideology of left-wing party, with a value of } \\
1 \text { if the incumbent is a member of the Social } \\
\text { Democratic Party (SDP) or a coalition in which } \\
\text { this party participates ( } 2009 \text { and } 2013 \text { local } \\
\text { elections) }\end{array}$ & $\begin{array}{l}\text { State Electoral Commission } \\
\text { (2009), State Electoral } \\
\text { Commission (2013) }\end{array}$ \\
\hline LIBERAL & $\begin{array}{l}\text { dummy variable denoting the political } \\
\text { ideology of liberal party, with a value of } 1 \\
\text { if the incumbent is a member of the Istrian } \\
\text { Democratic Assembly (IDS) or a coalition in } \\
\text { which this party participates ( } 2009 \text { and } 2013 \\
\text { local elections) }\end{array}$ & $\begin{array}{l}\text { State Electoral Commission } \\
\text { (2009), State Electoral } \\
\text { Commission (2013) }\end{array}$ \\
\hline RFCRIGHT & $\begin{array}{l}\text { the level of FC in the richer LGUs with a } \\
\text { right-wing incumbent* (2009 and } 2013 \text { local } \\
\text { elections) }\end{array}$ & $\begin{array}{l}\text { Ministry of Finance (2017) and } \\
\text { State Electoral Commission } \\
\text { (2009), State Electoral } \\
\text { Commission (2013) }\end{array}$ \\
\hline
\end{tabular}

determined by the fact that, in 2013, a random sample of 100 municipalities was chosen for measuring the dependent variable (OLBT). In 2013 and 2014, there was simply no capacity to measure OLBT for all 428 Croatian municipalities. 
Katarina Ott, Velibor Mačkić, Mihaela Bronić • Political Stubbornness and Online... Zb. rad. Ekon.fak. Rij. • 2019 • vol. $37 \cdot$ no. $2 \cdot 553-585$

\begin{tabular}{|l|l|l|}
\hline \multicolumn{1}{|c|}{ Variable } & \multicolumn{1}{|c|}{ Description } & \multicolumn{1}{|c|}{ Source } \\
\hline Independent, political competition & $\begin{array}{l}\text { linning margin or difference in the percentage } \\
\text { points between the incumbent and the runner up } \\
\text { in the first round of elections (2009 and 2013 } \\
\text { local elections) }\end{array}$ & $\begin{array}{l}\text { State Electoral Commission } \\
\text { (2009), State Electoral } \\
\text { Commission (2013) }\end{array}$ \\
\hline TOV & $\begin{array}{l}\text { turnout of voters in percentages in the local } \\
\text { elections (2009 and 2013 local elections) }\end{array}$ & $\begin{array}{l}\text { State Electoral Commission } \\
\text { (2009), State Electoral } \\
\text { Commission (2013) }\end{array}$ \\
\hline HHGOV & $\begin{array}{l}\text { Herfindahl-Hirschman index of the local } \\
\text { assembly calculated as the sum of the squared } \\
\text { seat shares of two biggest parties/coalitions in } \\
\text { the government (2009 and 2013 local elections) }\end{array}$ & $\begin{array}{l}\text { State Electoral Commission } \\
\text { (2009), State Electoral } \\
\text { Commission (2013) }\end{array}$ \\
\hline Dependent variable & $\begin{array}{l}\text { a simply constructed data count index ranging } \\
\text { from 0 to 3 measured by the annual number of } \\
\text { the three local documents - executive budget } \\
\text { proposal, enacted budget and citizens' guide - } \\
\text { published on the website of each municipality } \\
\text { and city (2013-2017) }\end{array}$ & Ott et al. (2017) \\
\hline OLBT &
\end{tabular}

Note: *From January 1, 2015, to January 1, 2016, there were two changes in the personal income tax sharing system between central and local governments (one big and the other smaller one affecting only a small fragment of LGUs).

Source: Authors' systematization

The control variables include population $(P O P)$, residents' income per capita (INC), fiscal capacity per capita $(F C)$, and internet access (INTERNET). The political ideology variables are political ideology of right-wing parties (RIGHT), political ideology of left-wing party (LEFT), political ideology of liberal party (LIBERAL), and the level of fiscal capacity in the richer LGUs with a right-wing incumbent $(R F C R I G H T)$. Political competition variables are winning margin $(W M)$, turnout of voters in percentages in the local elections $(\mathrm{TOV})$, and a Herfindahl-Hirschman index of the local assembly ( $H H G O V)$.

Table 2 provides descriptive statistics for the dependent variable OLBT and the remaining nine independent variables in the 2013-2017 period. The first part refers to the total sample (128 cities and 100 municipalities), while the second and third parts refer to the city and the municipality sample, respectively. Variables $T O V$ and $H H G O V$ are not included in the further analysis since they do not significantly contribute to the explanation of the dependent variable. 
Katarina Ott, Velibor Mačkić, Mihaela Bronić • Political Stubbornness and Online...

Table 2: Descriptive statistics

\begin{tabular}{|c|c|c|c|c|c|}
\hline & Obs. & Mean & Std. Dev. & Min. & Max. \\
\hline OLBT & 1135 & 1.179736 & 0.9216837 & 0 & 3 \\
\hline INC & 1135 & 10.10154 & 0.2850981 & 9.100087 & 10.87998 \\
\hline $\mathrm{FC}$ & 1135 & 3.074513 & 3.788127 & 0 & 9.307621 \\
\hline RIGHT & 1135 & 0.5127753 & 0.5000571 & 0 & 1 \\
\hline WM & 1135 & 23.26525 & 21.32724 & 0 & 100 \\
\hline POP & 1135 & 8.65628 & 1.119838 & 5.666427 & 13.59692 \\
\hline INTERNET & 1135 & 46.02301 & 15.67744 & 0 & 116.3099 \\
\hline \multicolumn{6}{|l|}{ City sample* } \\
\hline OLBT & 635 & 1.407874 & 0.9342422 & 0 & 3 \\
\hline INC & 635 & 10.22643 & 0.1925057 & 9.719073 & 10.73738 \\
\hline $\mathrm{FC}$ & 635 & 3.150535 & 3.876562 & 0 & 9.307621 \\
\hline RIGHT & 635 & 0.4897638 & 0.5002893 & 0 & 1 \\
\hline WM & 635 & 19.71543 & 16.29036 & 0 & 100 \\
\hline POP & 635 & 9.325669 & 0.9700605 & 7.31322 & 13.59692 \\
\hline INTERNET & 635 & 49.86477 & 13.59638 & 12.60288 & 112.6886 \\
\hline LEFT & 635 & 0.2062992 & 0.4049668 & 0 & 1 \\
\hline RLFCPCRIGHT & 635 & 2.235401 & 3.592336 & 0 & 10.17448 \\
\hline \multicolumn{6}{|c|}{ Municipality sample } \\
\hline OLBT & 500 & 0.89 & 0.8192939 & 0 & 3 \\
\hline INC & 500 & 9.942934 & 0.3042644 & 9.100087 & 10.87998 \\
\hline $\mathrm{FC}$ & 500 & 2.977965 & 3.674339 & 0 & 9.080471 \\
\hline RIGHT & 500 & 0.542 & 0.4987319 & 0 & 1 \\
\hline WM & 500 & 27.77352 & 25.69238 & 0 & 100 \\
\hline POP & 500 & 7.806155 & 0.5999088 & 5.666427 & 9.350711 \\
\hline INTERNET & 500 & 41.14398 & 16.76762 & 0 & 116.3099 \\
\hline LIBERAL & 500 & 0.026 & 0.1592945 & 0 & 1 \\
\hline
\end{tabular}

Note: *Popovača was classified as a municipality in 2013 when the project started (collecting the data and observing on-line local budget transparency) and remained in that sample in this analysis. Consequently, there are 127 cities in our sample.

Source: Authors' calculations

In the 2013-2017 period, cities and municipalities, on average, published 1.2 out of 3 documents (so, it can be concluded that they are not very transparent). The mean value of OLBT is almost $50 \%$ higher in the city sample than in the municipality sample, while the mean value of the total sample is situated between them. The similar finding applies for two control variables (INC and $F C$ ), while in the case of variables that denote ideology (RIGHT) and political competition (WM), one can 
report exactly the opposite. The mean value of right-wing ideology (RIGHT), and especially of the variable $(W M)$, is higher in the municipality sample than in the city sample, pointing to lower political competition and the stronger presence of rightwing ideology at the municipality level. Additionally, in approximately $50 \%$ of the analyzed LGUs in both the 2009 and 2013 elections, the right-wing incumbent was elected. ${ }^{11}$ Mean values of POP (log value of population) and INTERNET point to the expected conclusion since they are higher in city sample compared to the municipality sample

In addition, on average, in the period $2013-2017,33 \%$ of the analyzed LGUs published budget proposals, $70 \%$ enacted budgets and only $12 \%$ citizens' guides. Obviously, in accordance with rule-of-law theory, more LGUs have published mandatory documents (enacted budget) than voluntary documents (budget proposal and citizens' guide).

Table 3 shows the results of panel model estimations with fixed effects based on the Poisson distribution. ${ }^{12}$

Six models are presented; of these, a baseline model is estimated in all three samples: total (city plus municipality), city, and municipality subsamples. In addition, two models are estimated in the city sample and one model in the municipality sample. These additional models differ with respect to ideology (they capture the effect of left-wing and liberal parties) or include an interaction variable connected to ideology (RFCRIGHT - level of fiscal capacity in the richer LGUs with a right-wing incumbent). With respect to the ideological variables (denoting leftist and liberal political views), a positive coefficient based on the theoretical and empirical literature is expected to be obtained. On the other hand, the goal of the interaction variable is to test whether ideology triumphs over economics, i.e., the intention is to check whether richer LGUs actually do increase their OLBT regardless of the ideological stance of the incumbent, or as is expected, richer units with right-wing incumbents actually reduce their level of OLBT.

${ }^{11}$ In 2009, the right-wing incumbent was elected in 109 LGUs, while, in 2013, in local elections, the right-wing incumbent was elected in 107 LGUs.

12 The empirical investigation also included ordered probit and multinominal logit models. Since the goodness-of-fit tests confirmed that the fixed effect Poisson panel models are optimal, these results are presented in the Appendix 3. In the remainder of the paper we analysed results from the FE Poisson model. 


\begin{tabular}{|c|c|c|c|c|c|c|c|c|c|c|c|c|c|c|c|}
\hline 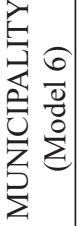 & $\frac{n}{\mathfrak{n}}$ & $\begin{array}{l}\frac{*}{*} \\
\stackrel{*}{\infty} \\
\stackrel{+}{+} \\
\stackrel{+}{e}\end{array}$ & 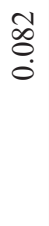 & 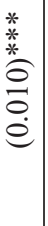 & & & $\begin{array}{l}1 \\
8 \\
0\end{array}$ & $\begin{array}{l}\stackrel{*}{\approx} \\
\stackrel{*}{8} \\
\stackrel{e}{e}\end{array}$ & & & $\stackrel{\hat{n}}{\tilde{\sigma}}$ & 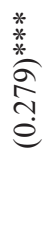 & $\begin{array}{l}0 \\
i \\
\infty \\
\infty\end{array}$ & 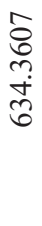 & $\frac{n}{\hat{\sigma}}$ \\
\hline 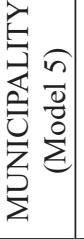 & $\begin{array}{l}\text { J } \\
\stackrel{-}{\sim}\end{array}$ & $\begin{array}{l}\stackrel{*}{*} \\
\stackrel{*}{\sigma} \\
\stackrel{+}{+} \\
\stackrel{d}{d}\end{array}$ & $\begin{array}{l}\tilde{O} \\
0 \\
0 \\
0\end{array}$ & 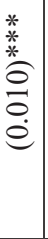 & $\begin{array}{l}\infty \\
\stackrel{\infty}{0} \\
0\end{array}$ & $\begin{array}{l}\stackrel{\vec{\Xi}}{\tilde{N}} \\
\stackrel{e}{e}\end{array}$ & $\begin{array}{l}0 \\
8 \\
0 \\
0\end{array}$ & $\begin{array}{l}\stackrel{*}{*} \\
\stackrel{*}{\delta} \\
\stackrel{e}{e}\end{array}$ & & & & & $\begin{array}{l}0 \\
\dot{0} \\
\infty \\
\dot{+}\end{array}$ & $\begin{array}{l}\overline{0} \\
n \\
n \\
n \\
\tilde{\sigma}\end{array}$ & 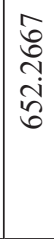 \\
\hline 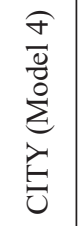 & $\begin{array}{l}\mathscr{2} \\
\stackrel{2}{r}\end{array}$ & $\begin{array}{l}\stackrel{*}{*} \\
\stackrel{*}{*} \\
\stackrel{n}{n} \\
\stackrel{c}{c}\end{array}$ & $\begin{array}{c}\text { กै } \\
\text { है } \\
0\end{array}$ & 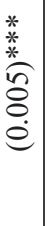 & & & $\begin{array}{l}0 \\
8 \\
0 \\
0 \\
1\end{array}$ & 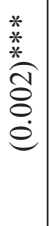 & $\frac{n}{2}$ & $\frac{\stackrel{*}{\cong}}{\stackrel{\Xi}{\varrho}}$ & & & $\begin{array}{l}0 \\
\text { రై } \\
\end{array}$ & $\begin{array}{l}m \\
\stackrel{2}{2} \\
\stackrel{2}{8}\end{array}$ & 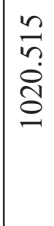 \\
\hline
\end{tabular}

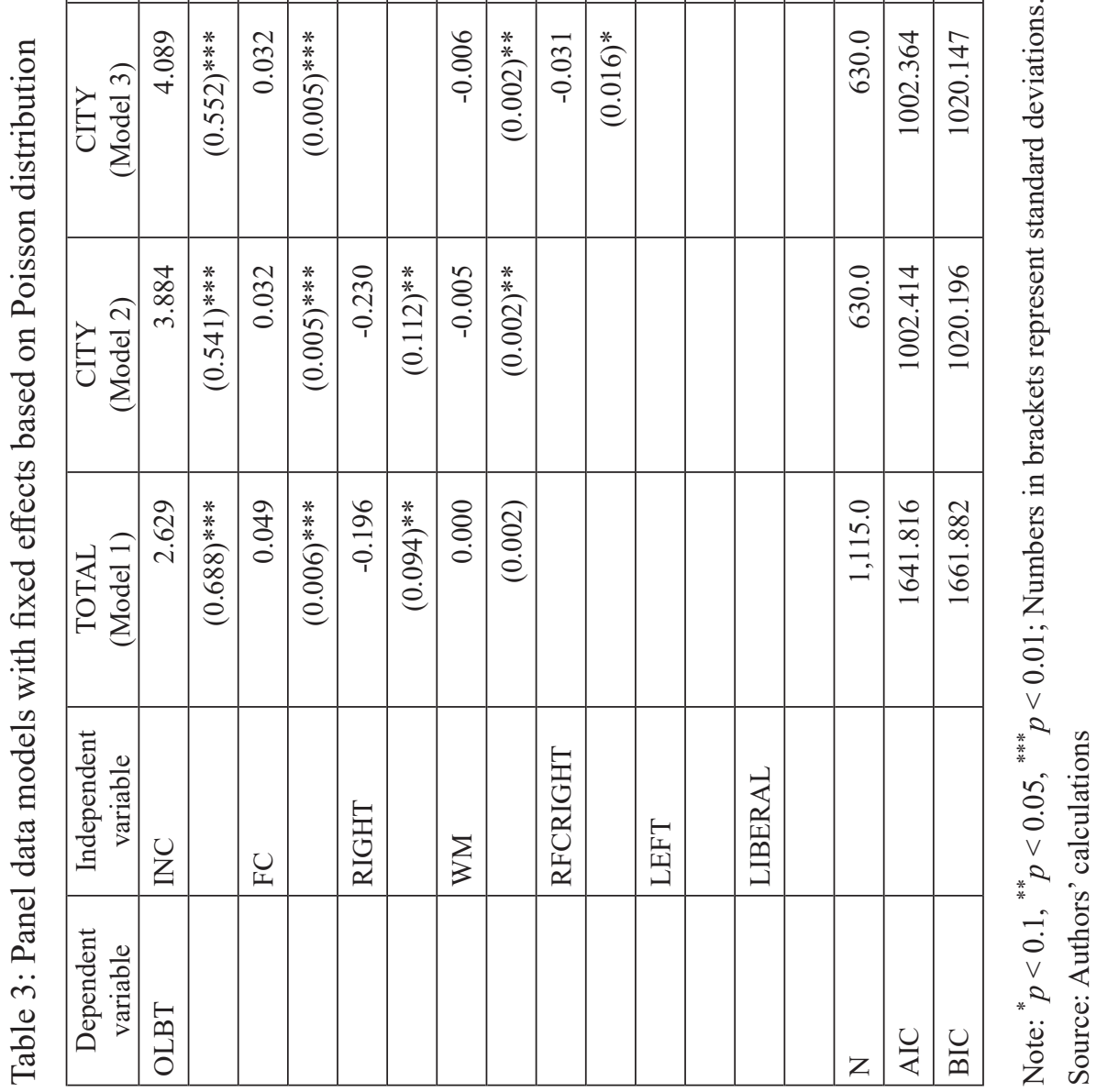


In the total sample, baseline model 1 confirms the expected negative and statistically significant influence of a right-wing incumbent (RIGHT) on the level of OLBT. As expected, both control variables (INC and $F C$ ) have a positive influence on the level of OLBT.

At the city level, baseline model 2, confirms the significant results obtained in the total sample (regarding RIGHT, INC and $F C$ ) and additionally reports a negative effect of the $W M$ on the level of OLBT. The higher the $W M$ (i.e. lower political competition) between the incumbent and the runner up is, the lower the level of OLBT. Model 3 includes an interaction variable that connects FC in richer cities (with FC higher than the average value of all units in the city sample) that have a right-wing incumbent (variable RFCRIGHT). The results again confirm a negative effect of a right-wing incumbent, with all the remaining variables $(I N C, F C$, and $W M$ ) holding their signs and the level of significance, as in baseline model 2. Model 4 includes an ideological variable that examines the effect of a left-wing incumbent on the level of OLBT and reports a positive effect. Of course, as was the case in the previous model 3, all the remaining variables $(I N C, F C$, and $W M$ ) kept their signs and level of significance vis-à-vis OLBT.

At the municipality level, baseline model 5, tells a different story vis-à-vis rightwing political ideology - it does not matter, although both control variables (INC and $F C$ ) maintain their expected positive relationship with the level of OLBT. The last "expanded" model 6 , includes an ideological variable that looks at the effect of a liberal incumbent and the level of OLBT. This model indicates a positive effect of the political ideology of a liberal party (LIBERAL) on the level of OLBT, with all the other control variables in the model (INC and $F C$ ) holding their positive and statistically significant effects on the level of OLBT in the municipality sample. Another interesting result on this level concerns WM. On the municipality level (in both model 5 and 6) unexpectedly it shows positive effects on OLBT.

\section{Results and discussion}

With respect to the results presented in the Table 3 we can summarize the following conclusions. Paper presents three important results that add to the literature.

First, results on the total and the city level confirm, for the first time, our hypothesis that there is a negative and statistically significant relationship between a right-wing political incumbent (RIGHT) and the level of OLBT. Theoretical underpinnings for this conclusion can be found within the agency theory. Previous research (Ott, Mačkić \& Bronić, 2018; Ott et al., 2019) shows mixed results probably due to different methodology and time period investigated. This paper adds to the literature since it uses the longest available time period thus allowing for local elections and their effect on the OLBT to be properly included in the analysis. 
It is also shown that political stubbornness, sticking to the right-wing ideology, is actually detrimental to OLBT in the total and city samples in Croatia. This conclusion stems from the below-average OLBT result in the 2013-2017 period and from the fact that approximately half of the local incumbents elected in both the 2009 and 2013 local elections were right-wing incumbents. Our conclusion about political stubbornness and sticking to the right-wing ideology, expands the existing literature on incumbents' behavior (Mačkić, 2014) and fits well with larger literature that examines the effect of partisanship on LBT. Vuković (2017) explains how local incumbents in Croatia maximize their chances of staying in power for long periods of time by creating a small group of loyal but powerful supporters (the winning coalition). He argues that most likely because of low accountability and low transparency, local incumbents and the winning coalition can stay in power for long periods of time. Furthermore (Brender, 2003) also points that the local voting process might not reflect voters' evaluation of local government performance, because local elections are decided, in most cases, on the basis of national party preferences and, in many cases voters do not possess the required information to evaluate the performance of local governments.

Second important result, on the city level, confirms a positive relationship between a left-wing incumbent (LEFT) and the level of OLBT. This result has theoretical roots in Ferejohn (1999) model and is in line with Gandía et al. (2016). Furthermore, legitimacy theory argues that transparency has a positive impact on the public's perception of the incumbent; thus, left-wing incumbents defending larger budgets should be more anxious for their constituencies to ascribe legitimacy to their actions. In line with legitimacy theory - model 6, estimated at the municipality level, also indicates a positive effect of the political ideology of a liberal party (LIBERAL) on the level of OLBT - our third important result.

Our hypothesis that there is a positive and statistically significant relationship between political competition and the level of OLBT is confirmed only on the city level. The higher the $W M$ between the incumbent and the runner up is (i.e. lower competition), the lower the level of OLBT. This result is theoretically expected and in line with da Cruz et al. (2016). Agents respond to the principal's demands under the threat of being replaced if they act otherwise. However, models estimated on the municipality level report different story and point to positive effect of the $W M$ on the level of OLBT (the lower the competition, the higher level of OLBT). Since this is not theoretically excepted result; more research is needed in order to further investigate the effect of $W M$ on the level of OLBT.

Furthermore, the positive effect of residents' income per capita (INC) in all three samples is an established result in the literature, as shown by Giroux and McLelland (2003), Piotrowski and Van Ryzin (2007) and Styles and Tennyson (2007). It might be that, as argued by previous authors, residents with higher incomes have more access to and experience with the internet and, thus, demand more OLBT. If one 
assumes self-interest on behalf of citizens, as agency theory does, then it follows logically that high-earning individuals who face higher marginal tax rates are more interested in budget transparency.

In line with studies conducted by Laswad et al. (2005) and Guillamón et al. (2011) this paper also confirms the positive relationship between the measure of fiscal capacity $(F C)$ and OLBT in all three samples. In other words, richer LGUs with better fiscal conditions offer more online budget information. Muñoz et al. (2016) state that, according to the agency and legitimacy theory, incumbents in richer LGUs have more interest in signaling efficient management skills by increasing the voluntary dissemination of information due to higher concerns about losing their appointments.

The paper offers three types of policy recommendations. First, the government should find a way to stimulate "less wealthy" LGUs and those with citizens of lower incomes to publish more key local budget documents online. Second, the online publication of key local budget documents should be prescribed by law since in, accordance with rule-of-law theory, LGUs are more willing to publish documents if they are prescribed by law. Third, since right-wing political parties publish fewer key local budget documents online, voters should think more about whom they are voting for and central government how to encourage political competition on the local level (e.g. introducing term limits to local incumbents).

\section{Conclusion}

This study empirically pinpoints determinants of OLBT in Croatia from 20132017 for a unique dataset of 128 cities and 100 municipalities. Using a fixed effects Poisson model, this research indicates that political ideology (hypothesis 1) and political competition (hypothesis 2) determine the level of OLBT. The paper reports a negative and statistically significant relationship, on a total and the city level, between a right-wing political incumbent and the level of OLBT. At the same time, only at the city level results indicate a positive relationship between political competition and OLBT. The two control variables (residents' income per capita and LGU's fiscal capacity) show a positive relationship with the level of OLBT. This work contributes to the literature in several ways. First, these results represent an initial attempt at empirically validating these links on a sample that is still largely neglected in empirical research - a fiscally centralized, post-socialist, EU member state. Second, this research uses the original measure of OLBT, which can easily be replicated and collected for other countries and/or regions. Third, the results are calculated by applying a novel methodology to this unique and new dataset. Fourth, the results are robust since they show both the clear negative effect of rightwing incumbents at the total and city levels on the one side and the positive effect of left-wing (at the city level) and liberal incumbents (at the municipality level). 
This effect was not achieved by any previous studies on OLF/BT. Finally, this research confirms that political competition has an impact on the local level online budget transparency. Limitations of the research stem foremost from the narrow municipality base (only 100 units) which can be corrected for in the upcoming time period. Also it would be interesting to see would the results of the analysis change if the City of Zagreb, which has a unique status of city and county and it is the largest city in Croatia, is excluded. More research is needed in order to further investigate the effect of political competition variables on the level of OLBT/BT. Also, future research might focus more on the puzzling issues of the institutional and political economy aspect of OLBT, i.e., the factors that might better explain the consistent stubbornness of citizens voting for nontransparent politicians. However, the obtained results do indicate certain areas that should be addressed by the public policy officials. Mandatory prescription of online budget documents and limitations of term in office at the local level are only part of those that could and should be accompanied by incentives aimed at economically underdeveloped local units in Croatia. The combination of sticks and carrots should result in optimal outcomes vis-à-vis online local budget transparency in Croatia.

\section{References}

Act on the Right of Access to Information (2013) Zakon o Pravu na Pristup Informacijama. NN 25/13, 85/15, Zagreb: Narodne novine.

Araujo, J.F.F.E. \& Tejedo-Romero, F. (2017) "Does Gender Equality Affect Municipal

Transparency: The Case of Spain", Public Performance \& Management Review,

Vol. 41, No. 1, pp. 69-99, http://dx.doi.org/10.1080/15309576.2017.1362350.

Araujo, J.F.F.E.d. \& Tejedo-Romero, F. (2016) "Local Government Transparency Index: Determinants of Municipalities' Rankings", International Journal of Public Sector Management, Vol. 29, No. 4, pp. 327-347, http://dx.doi. org/10.1108/IJPSM-11-2015-0199.

Birskyte, L. (2018) "Determinants of Budget Transparency in Lithuanian Municipalities“, Public Performance and Management Review, Vol. 42, No. 3, pp. 707-731, http://dx.doi.org/10.1080/15309576.2018.1507915.

Brender, A. (2003) "The effect of fiscal performance on local government election results in Israel : 1989 - 1998“, Journal of Public Economics, Vol. 87, pp. $2187-$ 2205, http://dx.doi.org/10.1016/S0047-2727(02)00045-2.

Budget Act. (2012) Zakon o Proračunu, NN 87/08, 136/12, 15/15, Zagreb: Narodne Novine.

Caamaño-Alegre, J. et al. (2013) "Budget Transparency in Local Governments: An Empirical Analysis", Local Government Studies, Vol. 39, No. 2, pp. 182-207, http://dx.doi.org/10.1080/03003930.2012.693075. 
Chen, C., \& Han, Y. (2019) "Following the money: The political determinants of E-fiscal transparency in US states", Public Management Review, Vol. 21, No. 5, pp. 732-754, http://dx.doi.org/10.1080/14719037.2018.1523451.

Corella, B.S. (2011) Regional Chapter, Citizen Engagement to Enhance Accountability and Prevent Corruption in the Provision of Public Services in OECD, New York: United Nations Public Administration Network.

Croatian Bureau of Statistics (CBS) (2017) Census 2011. MS Excel Tables, Zagreb: Croatian Bureau of Statistics.

Croatian Regulatory Authority for Network Industries (2018) Access to the Internet, Zagreb: Croatian Regulatory Authority for Network Industries (HAKOM).

da Cruz, N. F. et al. (2016) "Measuring Local Government Transparency", Public Management Review, Vol. 18, No. 6, pp. 866-893, http://dx.doi.org/10.1080/147 19037.2015.1051572.

del Sol, D.A. (2013) "The Institutional, Economic and Social Determinants of Local Government Transparency", Journal of Economic Policy Reform, Vol. 16, No. 1, pp. 90-107, http://dx.doi.org/10.1080/17487870.2012.759422.

Esteller-Moré, A. \& Otero, P.J. (2012) "Fiscal Transparency. (Why) Does your Local Government Respond?", Public Management Review, Vol. 14, No. 8, pp. 11531173, http://dx.doi.org/10.1080/14719037.2012.657839.

Ferejohn, J. (1986) "Incumbent Performance and Electoral Control", Public Choice, Vol. 50, No. 1, pp. 5-25, http://dx.doi.org/10.1007/BF00124924.

Ferejohn, J. (1999) "Accountability and Authority: Toward a Theory of Political Accountability". In Przeworski, A. et al. eds., Democracy, Accountability, and Representation, Cambridge: Cambridge University Press.

Gandía, J.L. \& Archidona, M.C. (2008) "Determinants of Web Site Information by Spanish City Councils", Online Information Review, Vol. 32, No. 1, pp. 35-57, http://dx.doi.org/10.1108/14684520810865976.

Gandía, J. L., Marrahí, L. and Huguet, D. (2016) "Digital transparency and Web 2.0 in Spanish city councils", Government Information Quarterly. Vol. 33, No. 1, pp. 28-39, http://dx.doi.org/10.1016/j.giq.2015.12.004.

García-Tabuyo, M., Sáez-Martín, A. \& Caba-Pérez, M.D.C. (2016) "Mandatory Versus Voluntary Disclosures: Drivers of Proactive Information Provision by Local Governments in Central America", Information Development, Vol. 32, No. 4, pp. 1199-1215, http://dx.doi.org/10.1177/0266666915595260.

García, A.C. \& García, J.G. (2008) "Determinantes de la Divulgación de Información Contable a Través de Internet Por Parte de Los Gobiernos Locales", Spanish Journal of Finance and Accounting/Revista Española de Financiación y Contabilidad, Vol. 37, No. 137, pp. 63-84, http://dx.doi.org/10.1080/02102412.2 008.10779639.

Gesuele, B. \& Metallo, C. (2017) "Factors Influencing Mandatory and Voluntary E-Disclosure Diffusion by Municipalities". In Corsi, K. et al. eds., Reshaping 
Accounting and Management Control Systems: New Opportunities from Business Information Systems, Cham, Switzerland: Springer International Publishing.

Giroux, G. and McLelland, A. J. (2003) "Governance structures and accounting at large municipalities", Journal of Accounting and Public Policy, Vol. 22, No. 3, pp. 203-230, http://dx.doi.org/10.1016/S0278-4254(03)00020-6.

Grimmelikhuijsen, S.G. \& Welch, E.W. (2012) "Developing and Testing a Theoretical Framework for Computer-Mediated Transparency of Local Governments", Public Administration Review, Vol. 72, No. 4, pp. 562-571, http://dx.doi.org/10.1111/j.1540-6210.2011.02532.x.

Guillamón, M.-D., Bastida, F. \& Benito, B. (2011) "The Determinants of Local Government's Financial Transparency", Local Government Studies, Vol. 37, No. 4, pp. 391-406, http://dx.doi.org/10.1080/03003930.2011.588704.

Hausman, J. (1978) „Specification Tests in Econometrics“, Econometrica, Vol. 46, No. 6, pp. 1251-1271, http://dx.doi.org/10.2307/1913827.

Hoffman, A.J. (2001) "Linking Organizational and Field-Level Analyses: The Diffusion of Corporate Environmental Practice", Organization \& Environment, Vol. 14, No. 2, pp. 133-156, http://dx.doi.org/10.1177/1086026601142001.

IAS Score (2018) “Concept of Rule of Law”, [Internet], Available at: <https:// iasscore.in/national-issues/concept-of-rule-of-law> [Accessed: October, 3, 2018].

International Budget Partnership (IBP) (2018) Open Budget Survey 2017, Washington, DC: International Budget Partnership.

Kopits, M.G. \& Craig, M.J. (1998) Transparency in Government Operations, Washington DC: International monetary fund.

Lassen, D.D. (2000) Political Accountability and he Size of Government: Theory and Cross-Country Evidence, EPRU Working Paper Series 00-20, Economic Policy Research Unit (EPRU), Copenhagen: Department of Economics, University of Copenhagen.

Laswad, F., Fisher, R. and Oyelere, P. (2005) "Determinants of voluntary Internet financial reporting by local government authorities", Journal of Accounting and Public Policy, Vol 24, No. 2, pp. 101-121, http://dx.doi.org/10.1016/j. jaccpubpol.2004.12.006.

Lowatcharin, G. \& Menifield, C.E. (2015) "Determinants of Internet-Enabled Transparency at the Local Level: A Study of Midwestern County Web Sites", State and Local Government Review, Vol. 47, No. 2, pp. 102-115, http://dx.doi. org/10.1177/0160323X15593384.

Ma, L., \& Wu, J. (2011) „What Drives Fiscal Transparency?“, Evidence from Provincial Governments in China. SSRN Electronic Journal, http://dx.doi. org/10.2139/ssrn.1807767.

Mačkić, V. (2014) "Political Budget Cycles at the Municipal Level in Croatia", Financial Theory and Practice, Vol. 38, No. 1, pp. 1-35, http://dx.doi.org/ 10.3326/fintp.38.1.1. 
Martinez-Vazquez, J. \& Timofeev, A. (2008) "Regional-Local Dimension of Russia's Fiscal Equalization", Journal of Comparative Economics, Vol. 36, No. 1, pp. 157-176, http://dx.doi.org/10.1016/j.jce.2007.04.004.

Ministry of Finance (2012) Upute za Izradu Proračuna Jedinica Lokalne i Područne (Regionalne) Samouprave za Razdoblje 2013. - 2015, Zagreb: Ministry of Finance.

Ministry of Finance (2017) Ostvarenje Proračuna JLP(R)S za Period 2012. -2016, Zagreb: Ministry of Finance.

Ministry of Regional Development and EU Funds (2017) Average Residents Income Per Capita 2012-2016, Zagreb: Ministry of Regional Development and European Union Funds.

Mundlak, Y. (1978) „On the Pooling of Time Series and Cross Section Data, Econometrica, Vol. 46, No. 1, pp. 69-85, http://dx.doi.org/10.2307/1913646.

Muñoz, A.L., Bolívar, R.M.P. \& Hernández, L.A.M. (2016) “Transparency in Governments: A Meta-Analytic Review of Incentives for Digital Versus HardCopy Public Financial Disclosures", The American Review of Public Administration, Vol. 47, No. 5, pp. 550-573, http://dx.doi.org/10.1177/ 0275074016629008.

OECD (2002) "OECD Best Practices for Budget Transparency", OECD Journal on Budgeting, Vol. 1, No. 3, pp. 7-14, http://dx.doi.org/10.1787/budget-v1-art14-en.

Ott, K. \& Bronić, M. (2015) "Public Participation in Fiscal Policy and Budget Processes in Croatia” [Internet], Available at: <http://www.fiscaltransparency. net/resourcesfiles/files/20150706114.pdf $>$ [Accessed: November, 4, 2018].

Ott, K. et al. (2017) "Budget Transparency in Croatian Counties, Cities and Municipalities (November 2016 - March 2017)", Newsletter - an Occasional Publication of the Institute of Public Finance, Vol. 18, No. 112, pp. 1-13, http:// dx.doi.org/10.3326/nle.2017.112.

Ott, K., Mačkić, V. \& Bronić, M. (2018), "Budget Transparency of Local Governments: The Political Economy of City and Municipality Budgets in Croatia", Društvena istraživanja, Vol. 27, No. 4, pp. 629-647, http://dx.doi. org/10.5559/di.27.4.03.

Ott, K. et al. (2019) "Determinants of voluntary online local budget transparency : a case study from Croatia", Ekonomski pregled, Vol. 70, No. 2, pp. 145-172, http:// dx.doi.org/10.32910/ep.70.2.1.

Pina, V., Torres, L. \& Royo, S. (2010) "IS E-Government Leading to more Accountable and Transparent Local Governments? An Overall View", Financial Accountability \& Management, Vol. 26, No. 1, pp. 3-20, http://dx.doi. org/10.1111/j.1468-0408.2009.00488.x.

Piotrowski, S.J. \& Van Ryzin, G.G. (2007) "Citizen Attitudes Toward Transparency in Local Government", The American Review of Public Administration, Vol. 37, No. 3, pp. 306-323, http://dx.doi.org/10.1177/0275074006296777. 
Puron-Cid, G. \& Bolívar, M.P.R. (2017) "The Effects of Contextual Factors into Different Features of Financial Transparency at the Municipal Level", Government Information Quarterly, Vol. 35, No. 1, pp. 135-150, http://dx.doi. org/10.1016/j.giq.2017.10.005.

Ríos, A.-M., Benito, B. \& Bastida, F. (2013) "Determinants of Central Government Budget Disclosure: An International Comparative Analysis", Journal of Comparative Policy Analysis: Research and Practice, Vol. 15, No. 3, pp. 235254, http://dx.doi.org/10.1080/13876988.2013.798449.

Ríos, A. M., Benito, B., \& Bastida, F. (2017) "Factors Explaining Public Participation in the Central Government Budget Process", Australian Journal of Public Administration, Vol. 76, No. 1, pp. 48-64, http://dx.doi.org/10.1111/14678500.12197.

Sedmihradská, L. (2015) "Budget Transparency in Czech Local Government", Procedia Economics and Finance, Vol. 25, pp. 598-606, http://dx.doi. org/10.1016/S2212-5671(15)00774-1.

Serrano-Cinca, C., Rueda-Tomás, M. \& Portillo-Tarragona, P. (2008) Factors Influencing E-Disclosure in Local Public Administrations, Zaragoza: Facultad de Ciencias Económicas Y Empresariales.

Stanić, B. (2018) "Determinants of subnational budget / fiscal transparency : a review of empirical evidence", Public Sector Economics, Vol. 42, No. 4, pp. 449-486, http://dx.doi.org/10.3326.pse.42.4.4.

State Electoral Commission (2009) Izbori 2009: Konačni Službeni Rezultati za Lokalne Izbore, Zagreb: State Electoral Commission.

State Electoral Commission (2013) Izbori 2013: Konačni Službeni Rezultati za Lokalne Izbore, Zagreb: State Electoral Commission.

Styles, A.K. \& Tennyson, M. (2007) "The Accessibility of Financial Reporting of U.S. Municipalities on the Internet", Journal of Public Budgeting, Accounting \& Financial Management, Vol. 19, No. 1, pp. 56-92, http://dx.doi.org/10.1108/ JPBAFM-19-01-2007-B003.

Tavares, A.F. \& da Cruz, N.F. (2014) "The Determinants of Local Government Transparency". In Paper Presented at the 8th International Conference on Theory and Practice of Electronic Governance - ICEGOV '14, New York, NY: ACM Press, pp. 117-123.

The World Bank (2015) Budget Transparency: What, Why, and How? Using Budgets to Empower People, Washington, DC: The World Bank.

Vuković, V. (2017) "The Political Economy of Local Government in Croatia: Winning Coalitions, Corruption, and Taxes", Public Sector Economics, Vol. 41, No. 4, pp. 387-420, http://dx.doi.org/10.3326/pse.41.4.1.

Weingast, B. R. (2009) „Second generation fiscal federalism: The implications of fiscal incentives“, Journal of Urban Economics, Vol. 65, No. 3, pp. 279-293, http://dx.doi.org/10.1016/j.jue.2008.12.005. 
Wehner, J. \& de Renzio, P. (2013) "Citizens, Legislators, and Executive Disclosure: The Political Determinants of Fiscal Transparency", World Development, Vol. 41, No. 1, pp. 96-108, http://dx.doi.org/10.1016/j.worlddev.2012.06.005.

Zimmerman, J.L. (1977) "The Municipal Accounting Maze: An Analysis of Political Incentives", Journal of Accounting Research, Vol. 15, pp. 107-144, http://dx.doi. org/10.2307/2490636. 


\title{
Politička tvrdoglavost i online proračunska transparentnost lokalnih jedinica $^{1}$
}

\author{
Katarina Ott ${ }^{2}$, Velibor Mačkić ${ }^{3}$, Mihaela Bronic ${ }^{4}$
}

\begin{abstract}
Sažetak
Online proračunska transparentnost lokalnih jedinica (OLBT) prepoznata je kao važna značajka dobrog upravljanja. U skladu s tim, OLBT se u ovom radu mjeri u svih 128 gradova i na uzorku od 100 općina u Hrvatskoj koristeći nekoliko ključnih lokalnih proračunskih dokumenata objavljenih na web stranicama lokalnih jedinica. Koristeći Poissonov panel model s fiksnim učinkom u razdoblju 2013. - 2017., pokazalo se da osim dohotka stanovnika i fiskalnog kapaciteta lokalnih jedinica, razinu OLBT-a određuju politička ideologija i politička konkurencija. Ovaj rad pridonosi rastućoj literaturi o proračunskoj transparentnosti utvrđivanjem važnosti političkih faktora kao odrednica OLBT-a u bivšoj socijalističkoj, fiskalno centraliziranoj, članici EU-a i otkriva zanimljivu tvrdoglavost građana koji dosljedno glasaju za netransparentne političare. Glavni nalaz je da su politički faktori (politička ideologija i politička konkurencija) važni kao odrednice OLBT-a, što u lokalnim jedinicama rezultira suboptimalnom ravnotežom s niskim razinama OLBT-a. Lokalni političar na vlasti zaključuje da OLBT nije od posebne važnost da bi mu izborna jedinica zamjerila netransparentnost. U takvom je okruženju navedeni zaključak valjan, jer ovaj rad dokazuje da birači, koji su tvrdoglavi u svojim glasačkim obrascima, odbijaju promijeniti lokalnog političara na vlasti iako je netransparentan.
\end{abstract}

Ključne riječi: online proračunska transparentnost, lokalne jedinice, Hrvatska, politička ekonomija, analiza panel podataka

JEL klasifikacija: H11, H70

1 Ovaj je rad nastao uz financijsku potporu Hrvatske zaklade za znanost [IP-2014-09-3008].

2 Profesor, viši istraživački savjetnik, Institut za javne financije, Smičiklasova 21, 10000 Zagreb, Hrvatska.Znanstveni interes: ekonomija javnog sektora.Tel.: +38514886444.E-mail: kott@ijf. hr. ORCiD: 0000-0003-2242-4181. Web stranica: http://www.ijf.hr/eng/employees/researchers/7/ katarina-ott-phd/1494/(osoba za kontakt).

${ }^{3}$ Docent, Ekonomski fakultet Sveučilišta u Zagrebu, Trg J. F. Kennedyja 6, 10000 Zagreb, Hrvatska. Znanstveni interes: analiza konkurentnosti, nova politička ekonomija, politički ciklusi.Tel.: +38512383201. E-mail:vmackic@efzg.hr. ORCiD: 0000-0002-3200-8571. Web stranica: http://www.efzg.unizg.hr/departments/economic-theory/fa fakultet-2831/velibormackic-phd/22082.

4 Viši znanstveni suradnik, Institut za javne financije, Smičiklasova 21, 10000 Zagreb, Hrvatska. Znanstveni interes: fiskalna decentralizacija $i$ razvoj, porezni sustav, transparentnost proračuna.Tel.: +38514886444.E-mail: mihaela.bronic@ijf.hr. ORCiD:0000-0002-08632040. Web stranica: http://www.ijf.hr/eng/employees/researchers/7/mihaela-bronic-phd/150/. 


\section{Appendices}

Table 4: Panel summary of variables

\begin{tabular}{|c|c|c|c|c|c|c|}
\hline \multicolumn{2}{|c|}{ Variable } & Mean & Std. Dev. & Min. & Max. & Observations \\
\hline \multicolumn{7}{|c|}{ TOTAL SAMPLE } \\
\hline \multirow[t]{3}{*}{ OLBI } & overall & 1.179736 & 0.9216837 & 0 & 3 & $\mathrm{~N}=1135$ \\
\hline & between & & 0.6852 & 0 & 3 & $\mathrm{n}=227$ \\
\hline & within & & 0.6177846 & -0.6202643 & 3.579736 & $t=5$ \\
\hline \multirow[t]{3}{*}{ INC } & overall & 10.10154 & .2850981 & 9.100087 & 10.87998 & $\mathrm{~N}=1135$ \\
\hline & between & & 0.2777634 & 9.351308 & 10.70162 & $\mathrm{n}=227$ \\
\hline & within & & 0.0663366 & 9.529458 & 10.9464 & $t=5$ \\
\hline \multirow[t]{3}{*}{$\mathrm{FC}$} & overall & 3.074513 & 3.788127 & 0 & 9.307621 & $\mathrm{~N}=1135$ \\
\hline & between & & 0.2501774 & 2.564352 & 3.702296 & $\mathrm{n}=227$ \\
\hline & within & & 3.779886 & -0.6277832 & 8.679837 & $t=5$ \\
\hline \multirow[t]{3}{*}{ RIGHT } & overall & 0.5127753 & 0.5000571 & 0 & 1 & $\mathrm{~N}=1135$ \\
\hline & between & & 0.465029 & 0 & 1 & $\mathrm{n}=227$ \\
\hline & within & & 0.1859245 & -0.2872247 & 1.312775 & $t=5$ \\
\hline \multirow[t]{3}{*}{ VM } & overall & 23.26525 & 21.32724 & 0 & 100 & $N=1135$ \\
\hline & between & & 19.1089 & 0.8 & 100 & $\mathrm{n}=227$ \\
\hline & within & & 9.538837 & -53.27075 & 99.94525 & $t=5$ \\
\hline \multirow[t]{3}{*}{ POP } & overall & 8.65628 & 1.119838 & 5.666427 & 13.59692 & $\mathrm{~N}=1135$ \\
\hline & between & & 1.121387 & 5.694245 & 13.59135 & $\mathrm{n}=227$ \\
\hline & within & & 0.0310595 & 8.491051 & 9.19339 & $t=5$ \\
\hline \multirow[t]{3}{*}{ INTERNET } & overall & 46.02301 & 15.67744 & 0 & 116.3099 & $\mathrm{~N}=1135$ \\
\hline & between & & 15.05049 & 1.64983 & 94.32444 & $\mathrm{n}=227$ \\
\hline & within & & 4.473731 & 13.30521 & 69.65945 & $t=5$ \\
\hline \multicolumn{7}{|c|}{ CITY SAMPLE } \\
\hline \multirow[t]{3}{*}{ OLBI } & overall & 1.407874 & 0.9342422 & 0 & 3 & $\mathrm{~N}=635$ \\
\hline & between & & 0.7101985 & 0 & 3 & $\mathrm{n}=127$ \\
\hline & within & & 0.6095973 & -0.392126 & 3.407874 & $t=5$ \\
\hline \multirow[t]{3}{*}{ INC } & overall & 10.22643 & 0.1925057 & 9.719073 & 10.73738 & $N=635$ \\
\hline & between & & 0.1880488 & 9.792834 & 10.70162 & $\mathrm{n}=127$ \\
\hline & within & & 0.0438083 & 10.05267 & 10.35409 & $t=5$ \\
\hline \multirow[t]{3}{*}{$\mathrm{FC}$} & overall & 3.150535 & 3.876562 & 0 & 9.307621 & $N=635$ \\
\hline & between & & 0.2138668 & 2.709845 & 3.702296 & $\mathrm{n}=127$ \\
\hline & within & & 3.870695 & -0.5517611 & 8.755859 & $t=5$ \\
\hline \multirow[t]{3}{*}{ RIGHT } & overall & 0.4897638 & 0.5002893 & 0 & 1 & $N=635$ \\
\hline & between & & 0.4609918 & 0 & 1 & $\mathrm{n}=127$ \\
\hline & within & & 0.1977795 & -0.3102362 & 1.289764 & $t=5$ \\
\hline
\end{tabular}


Katarina Ott, Velibor Mačkić, Mihaela Bronić • Political Stubbornness and Online...

\begin{tabular}{|c|c|c|c|c|c|c|}
\hline \multicolumn{2}{|c|}{ Variable } & \multirow{4}{*}{$\begin{array}{c}\text { Mean } \\
19.71543\end{array}$} & \multirow{4}{*}{$\begin{array}{r}\text { Std. Dev. } \\
16.29036 \\
14.27592 \\
7.92842\end{array}$} & \multirow{4}{*}{\begin{tabular}{r}
\multicolumn{1}{c}{ Min. } \\
0 \\
0.8 \\
-33.22057 \\
\end{tabular}} & \multirow{4}{*}{$\begin{array}{r}\text { Max. } \\
100 \\
86.766 \\
93.00343\end{array}$} & \multirow{4}{*}{$\begin{array}{c}\text { Observations } \\
\mathrm{N}=635 \\
\mathrm{n}=127 \\
\mathrm{t}=5\end{array}$} \\
\hline VM & overall & & & & & \\
\hline & between & & & & & \\
\hline & within & & & & & \\
\hline \multirow[t]{3}{*}{ POP } & overall & 9.325669 & 0.9700605 & 7.31322 & 13.59692 & $\mathrm{~N}=635$ \\
\hline & between & & 0.9726335 & 7.332029 & 13.59135 & $\mathrm{n}=127$ \\
\hline & within & & 0.0311448 & 9.16044 & 9.862779 & $t=5$ \\
\hline \multirow[t]{3}{*}{ INTERNET } & overall & 49.86477 & 13.59638 & 12.60288 & 112.6886 & $\mathrm{~N}=635$ \\
\hline & between & & 13.08431 & 23.89208 & 94.32444 & $\mathrm{n}=127$ \\
\hline & within & & 3.830849 & 31.12332 & 68.22894 & $t=5$ \\
\hline \multirow[t]{3}{*}{ LEFT } & overall & 0.2062992 & 0.4049668 & 0 & 1 & $\mathrm{~N}=635$ \\
\hline & between & & 0.3633504 & 0 & 1 & $\mathrm{n}=127$ \\
\hline & within & & 0.1811286 & -0.5937008 & 1.006299 & $t=5$ \\
\hline \multirow[t]{3}{*}{ RFCRIGHT } & overall & 2.235401 & 3.592336 & 0 & 10.17448 & $\mathrm{~N}=635$ \\
\hline & between & & 3.292889 & 0 & 8.929113 & $\mathrm{n}=127$ \\
\hline & within & & 1.459511 & -4.566551 & 9.082016 & $t=5$ \\
\hline \multicolumn{7}{|c|}{ MUNICIPALITY SAMPLE } \\
\hline \multirow[t]{3}{*}{ OLBI } & overall & 0.89 & 0.8192939 & 0 & 3 & $\mathrm{~N}=500$ \\
\hline & between & & 0.5275252 & 0 & 2.4 & $\mathrm{n}=100$ \\
\hline & within & & 0.6286417 & -0.51 & 3.29 & $t=5$ \\
\hline \multirow{3}{*}{ INC } & overall & 9.942934 & 0.3042644 & 9.100087 & 10.87998 & $\mathrm{~N}=500$ \\
\hline & between & & 0.2927487 & 9.351308 & 10.60634 & $\mathrm{n}=100$ \\
\hline & within & & 0.08696 & 9.370853 & 10.78779 & $t=5$ \\
\hline \multirow[t]{3}{*}{$\mathrm{FC}$} & overall & 2.977965 & 3.674339 & 0 & 9.080471 & $\mathrm{~N}=500$ \\
\hline & between & & 0.2604542 & 2.564352 & 3.603766 & $\mathrm{n}=100$ \\
\hline & within & & 3.66517 & -0.6258008 & 8.45467 & $t=5$ \\
\hline \multirow[t]{3}{*}{ RIGHT } & overall & 0.542 & 0.4987319 & 0 & 1 & $N=500$ \\
\hline & between & & 0.4707999 & 0 & 1 & $\mathrm{n}=100$ \\
\hline & within & & 0.1698756 & -0.258 & 1.342 & $t=5$ \\
\hline \multirow[t]{3}{*}{ VM } & overall & 27.77352 & 25.69238 & 0 & 100 & $\mathrm{~N}=500$ \\
\hline & between & & 23.18395 & 3.276 & 100 & $\mathrm{n}=100$ \\
\hline & within & & 11.2655 & -48.76248 & 104.4535 & $t=5$ \\
\hline \multirow[t]{3}{*}{ POP } & overall & 7.806155 & 0.5999088 & 5.666427 & 9.350711 & $\mathrm{~N}=500$ \\
\hline & between & & 0.601524 & 5.694245 & 9.342002 & $\mathrm{n}=100$ \\
\hline & within & & 0.0309819 & 7.670096 & 7.994199 & $t=5$ \\
\hline \multirow[t]{3}{*}{ INTERNET } & overall & 41.14398 & 16.76762 & 0 & 116.3099 & $\mathrm{~N}=500$ \\
\hline & between & & 16.00722 & 1.64983 & 92.67346 & $\mathrm{n}=100$ \\
\hline & within & & 5.181544 & 8.426177 & 64.78042 & $t=5$ \\
\hline \multirow[t]{3}{*}{ LIBERAL } & overall & 0.026 & 0.1592945 & 0 & 1 & $\mathrm{~N}=500$ \\
\hline & between & & 0.1382576 & 0 & 0.8 & $\mathrm{n}=100$ \\
\hline & within & & 0.0800801 & -0.774 & 0.826 & $t=5$ \\
\hline
\end{tabular}

Source: Authors' calculations 
Table 5: Model RE

\begin{tabular}{|l|l|}
\hline Random-effects GLS regression & Number of obs $=1,135$ \\
\hline Group variable: ID & Number of groups $=227$ \\
\hline R-sq: & Obs per group: \\
\hline within $=0.3013$ & $\min =5$ \\
\hline between $=0.2484$ & avg $=5.0$ \\
\hline overall $=0.2712$ & $\max =5$ \\
\hline & Wald chi2(4) $=463.59$ \\
\hline corr(u_i, $\mathrm{X})=0$ (assumed) & Prob $>$ chi2 $=0.0000$ \\
\hline
\end{tabular}

\begin{tabular}{|l|c|c|c|c|c|r|}
\hline \multicolumn{1}{|c|}{ OLBT } & \multicolumn{1}{c|}{ Coef. } & \multicolumn{1}{c|}{ Std. Err. } & \multicolumn{1}{c|}{$\mathrm{z}$} & $\mathrm{P}>\mathrm{z}$ & \multicolumn{2}{|c|}{$[95 \%$ Conf. Interval] } \\
\hline INC & 1.257597 & .1320288 & 9.53 & 0.000 & .9988251 & 1.516 .368 \\
\hline FC & .0738498 & .0047085 & 15.68 & 0.000 & .0646213 & .0830782 \\
\hline RIGHT & -.0801826 & .064091 & -1.25 & 0.211 & -.2057987 & .0454336 \\
\hline WM & -.001849 & .0013705 & -1.35 & 0.177 & -.0045351 & .0008372 \\
\hline cons & -11.66685 & 1.336858 & -8.73 & 0.000 & -14.28704 & -9.046 .656 \\
\hline
\end{tabular}

\begin{tabular}{|l|l|}
\hline sigma_u & .5399188 \\
\hline sigma_e & .57723139 \\
\hline rho & .46663742 (fraction of variance due to u_i) \\
\hline
\end{tabular}

Source: Authors' calculations 
Katarina Ott, Velibor Mačkić, Mihaela Bronić • Political Stubbornness and Online...

Table 6: Model Hybrid

\begin{tabular}{|l|l|}
\hline Random-effects GLS regression & Number of obs $=1,135$ \\
\hline Group variable: ID & Number of groups $=227$ \\
\hline R-sq: & Obs per group: \\
\hline within $=0.3040$ & $\min =5$ \\
\hline between $=0.2507$ & $\mathrm{avg}=5.0$ \\
\hline overall $=0.2746$ & $\max =5$ \\
\hline & Wald chi2 $(8)=469.15$ \\
\hline corr(u_i, $\mathrm{X})=0$ (assumed) & Prob $>\operatorname{chi} 2=0.0000$ \\
\hline
\end{tabular}

\begin{tabular}{|l|c|c|c|c|c|c|}
\hline \multicolumn{1}{|c|}{ OLBI } & Coef. & Std. Err. & $\mathrm{z}$ & $\mathrm{P}>\mathrm{z}$ & \multicolumn{2}{c|}{$[95 \%$ Conf. Interval] } \\
\hline diff_INC & 1.83498 & .3021889 & 6.07 & 0.000 & 1.242701 & 2.42726 \\
\hline diff_FC & .0688333 & .0052927 & 13.01 & 0.000 & .0584598 & .0792067 \\
\hline diff_RIGHT & -.0667035 & .0930152 & -0.72 & 0.473 & -.24901 & .1156029 \\
\hline diff_WM & -.0012479 & .0018172 & -0.69 & 0.492 & -.0048095 & .0023137 \\
\hline mean_INC & 1.20279 & .2091193 & 5.75 & 0.000 & .792924 & 1.612656 \\
\hline mean_FC & -.06577 & .2289895 & -0.29 & 0.774 & -.5145811 & .3830411 \\
\hline mean_RIGHT & -.1122455 & .0889327 & -1.26 & 0.207 & -.2865503 & .0620594 \\
\hline mean_WM & -.0020873 & .0021234 & -0.98 & 0.326 & -.0062491 & .0020745 \\
\hline cons & -10.66197 & 170.595 & -6.25 & 0.000 & -14.00557 & -7.318368 \\
\hline
\end{tabular}

\begin{tabular}{|l|l|}
\hline sigma_u & .53899336 \\
\hline sigma_e & .57723139 \\
\hline rho & .46578359 (fraction of variance due to u_i) \\
\hline
\end{tabular}

Source: Authors' calculations

Table 7: Mundlak test

\begin{tabular}{|c|l|}
\hline. test & mean_INC=mean_FC=mean_RIGHT=mean_WM==0 \\
\hline-1 & mean_INC - mean_FC $=0$ \\
\hline-2 & mean_INC - mean__RIGHT $=0$ \\
\hline-3 & mean__INC - mean_WM $=0$ \\
\hline-4 & mean_INC $=0$ \\
\hline & chi2 $(4)=74.43$ \\
\hline & Prob $>$ chi2 $=0.0000$ \\
\hline
\end{tabular}

Source: Authors' calculations 
Table 8: Poisson, ordered probit and multinominal logit - total sample

\begin{tabular}{|c|c|c|c|c|c|c|c|}
\hline & OLBT & \multicolumn{2}{|c|}{ POISSON } & \multicolumn{2}{|c|}{ OPROBIT } & \multicolumn{2}{|c|}{ MLOGIT } \\
\hline & INC & 2.629 & $(0.688)^{* * *}$ & 1.601 & $(0.134)^{* * *}$ & & \\
\hline & FC & 0.049 & $(0.006)^{* * *}$ & 0.101 & $(0.009)^{* * *}$ & & \\
\hline & RIGHT & -0.196 & $(0.094)^{* *}$ & -0.135 & $(0.068)^{* *}$ & & \\
\hline & WM & 0.000 & $(0.002)$ & -0.003 & $(0.002)^{* *}$ & & \\
\hline cut1 & cons & & & 15.532 & $(1.352)^{* * *}$ & & \\
\hline cut 2 & cons & & & 16.864 & $(1.363)^{* * *}$ & & \\
\hline cut3 & cons & & & 17.898 & $(1.370)^{* * *}$ & & \\
\hline \multirow[t]{5}{*}{0} & INC & & & & & -1.218 & $(0.263)^{* * *}$ \\
\hline & $\mathrm{FC}$ & & & & & -0.143 & $(0.025)^{* * *}$ \\
\hline & RIGHT & & & & & 0.068 & $(0.160)$ \\
\hline & WM & & & & & -0.001 & $(0.004)$ \\
\hline & cons & & & & & 11.953 & $(2.657)^{* * * *}$ \\
\hline \multirow[t]{5}{*}{2} & INC & & & & & 2.458 & $(0.417) * * *$ \\
\hline & $\mathrm{FC}$ & & & & & 0.077 & $(0.021) * * *$ \\
\hline & RIGHT & & & & & -0.044 & $(0.171)$ \\
\hline & WM & & & & & -0.014 & $(0.004)^{* * *}$ \\
\hline & cons & & & & & \begin{tabular}{|l|}
-25.469 \\
\end{tabular} & $(4.268)^{* * *}$ \\
\hline \multirow[t]{6}{*}{3} & INC & & & & & 5.768 & $(0.764)^{* * *}$ \\
\hline & $\mathrm{FC}$ & & & & & 0.231 & $(0.031) * * *$ \\
\hline & RIGHT & & & & & -0.335 & $(0.252)$ \\
\hline & WM & & & & & -0.008 & $(0.005)$ \\
\hline & cons & & & & & -61.156 & $(7.865)^{* * *}$ \\
\hline & $\mathrm{N}$ & \multicolumn{2}{|l|}{$1,115.0$} & \multicolumn{2}{|l|}{$1,135.0$} & \multicolumn{2}{|l|}{$1,135.0$} \\
\hline \multicolumn{2}{|l|}{ AIC } & \multicolumn{2}{|l|}{1641.816} & \multicolumn{2}{|l|}{2566.097} & \multicolumn{2}{|l|}{2544.469} \\
\hline \multicolumn{2}{|l|}{$\mathrm{BIC}$} & \multicolumn{2}{|l|}{1661.882} & \multicolumn{2}{|l|}{2601.338} & \multicolumn{2}{|l|}{2619.985} \\
\hline
\end{tabular}

Note: $* p<0.1 ; * * p<0.05 ; * * * p<0.01$; Numbers in brackets represent standard deviations.

Source: Authors' calculations 
Katarina Ott, Velibor Mačkić, Mihaela Bronić • Political Stubbornness and Online...

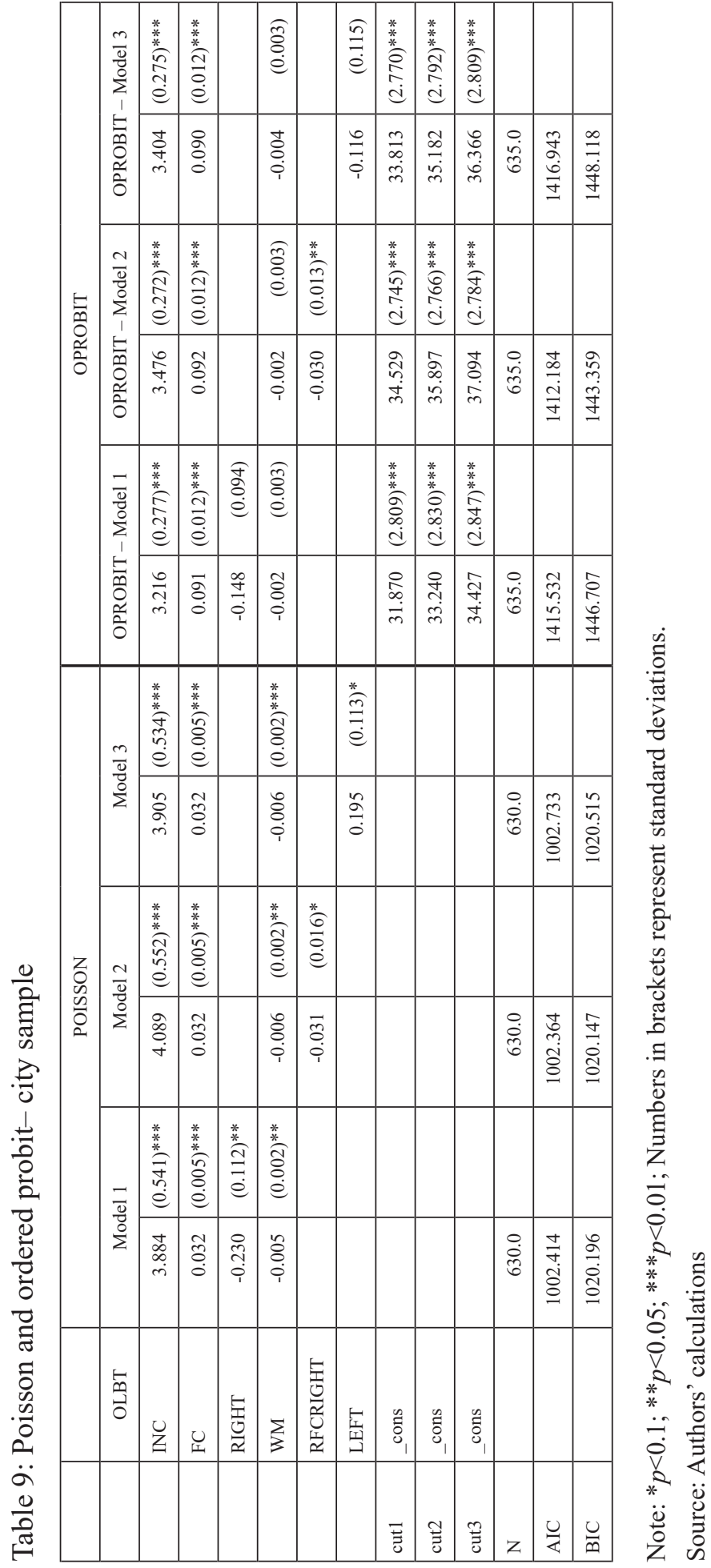


Table 10: Multinominal logit - city sample

\begin{tabular}{|c|c|c|c|c|c|c|c|}
\hline & OLBT & \multicolumn{2}{|c|}{ Model 1} & \multicolumn{2}{|c|}{ Model 2} & \multicolumn{2}{|c|}{ Model 3} \\
\hline \multirow[t]{5}{*}{0} & INC & -3.374 & $(0.756)^{* * *}$ & -3.830 & $(0.865)^{* * *}$ & -3.891 & $(0.778)^{* * *}$ \\
\hline & $\mathrm{FC}$ & -0.134 & $(0.039)^{* * *}$ & -0.131 & $(0.039)^{* * *}$ & -0.126 & $(0.039)^{* * *}$ \\
\hline & RIGHT & 0.286 & $(0.262)$ & & & & \\
\hline & WM & -0.007 & (0.009) & -0.006 & (0.009) & -0.002 & $(0.008)$ \\
\hline & cons & 33.604 & $(7.671)^{* * *}$ & 38.309 & $(8.728)^{* * *}$ & 38.803 & $(7.837)^{* * *}$ \\
\hline \multirow[t]{5}{*}{2} & INC & 3.621 & $(0.649)^{* * *}$ & 3.573 & $(0.619)^{* * *}$ & 3.600 & $(0.639)^{* * *}$ \\
\hline & $\mathrm{FC}$ & 0.065 & $(0.026)^{* *}$ & 0.066 & $(0.026)^{* *}$ & 0.066 & $(0.026) * *$ \\
\hline & RIGHT & 0.082 & $(0.219)$ & & & & \\
\hline & WM & -0.013 & $(0.007)^{*}$ & -0.013 & $(0.007)^{*}$ & -0.013 & $(0.007)^{* *}$ \\
\hline & cons & -37.316 & $(6.672)^{* * *}$ & -36.798 & $(6.325)^{* * *}$ & -37.059 & $(6.520)^{* * *}$ \\
\hline \multirow[t]{11}{*}{3} & INC & 8.887 & $(1.195)^{* * *}$ & 9.086 & $(1.125)^{* * *}$ & 9.289 & $(1.193)^{* * *}$ \\
\hline & $\mathrm{FC}$ & 0.230 & $(0.037)^{* * *}$ & 0.235 & $(0.038)^{* * *}$ & 0.227 & $(0.037)^{* * *}$ \\
\hline & RIGHT & -0.413 & $(0.319)$ & & & & \\
\hline & WM & -0.010 & $(0.008)$ & -0.010 & $(0.008)$ & -0.012 & $(0.008)$ \\
\hline & RFCRIGHT & & & 0.029 & $(0.042)$ & & \\
\hline & RFCRIGHT & & & 0.000 & $(0.027)$ & & \\
\hline & RFCRIGHT & & & -0.088 & $(0.042)^{* *}$ & & \\
\hline & LEFT & & & & & 0.551 & $(0.333)^{*}$ \\
\hline & LEFT & & & & & -0.034 & $(0.261)$ \\
\hline & LEFT & & & & & 0.035 & $(0.322)$ \\
\hline & cons & -93.192 & $(12.336)^{* * *}$ & -95.211 & $(11.605)^{* * *}$ & -97.458 & $(12.301)^{* * *}$ \\
\hline $\mathrm{N}$ & & 635.0 & & 635.0 & & 635.0 & \\
\hline \multicolumn{2}{|c|}{ AIC } & & 1420.838 & & 1418.118 & & 1421.593 \\
\hline \multicolumn{2}{|c|}{ BIC } & & 1487.643 & & 1484.922 & & 1488.397 \\
\hline
\end{tabular}

Note: ${ }^{*} p<0.1 ; * * p<0.05 ; * * * p<0.01$

Numbers in brackets represent standard deviations.

Source: Authors' calculations 
Katarina Ott, Velibor Mačkić, Mihaela Bronić • Political Stubbornness and Online...

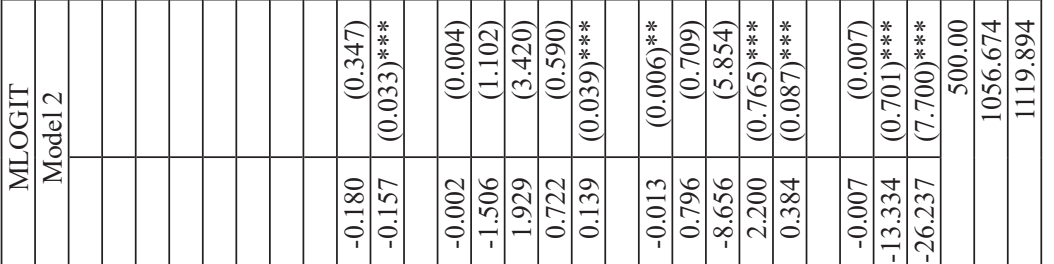

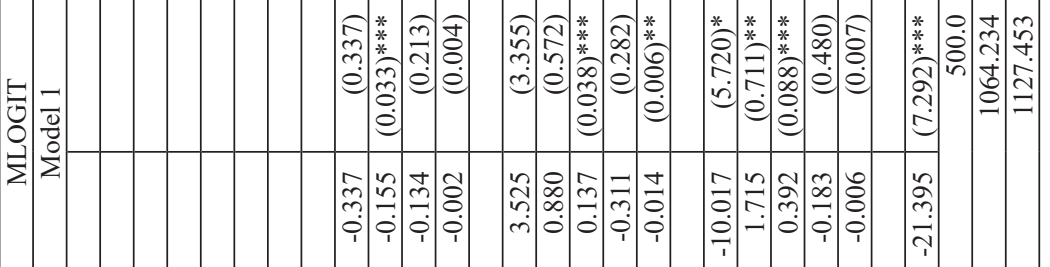

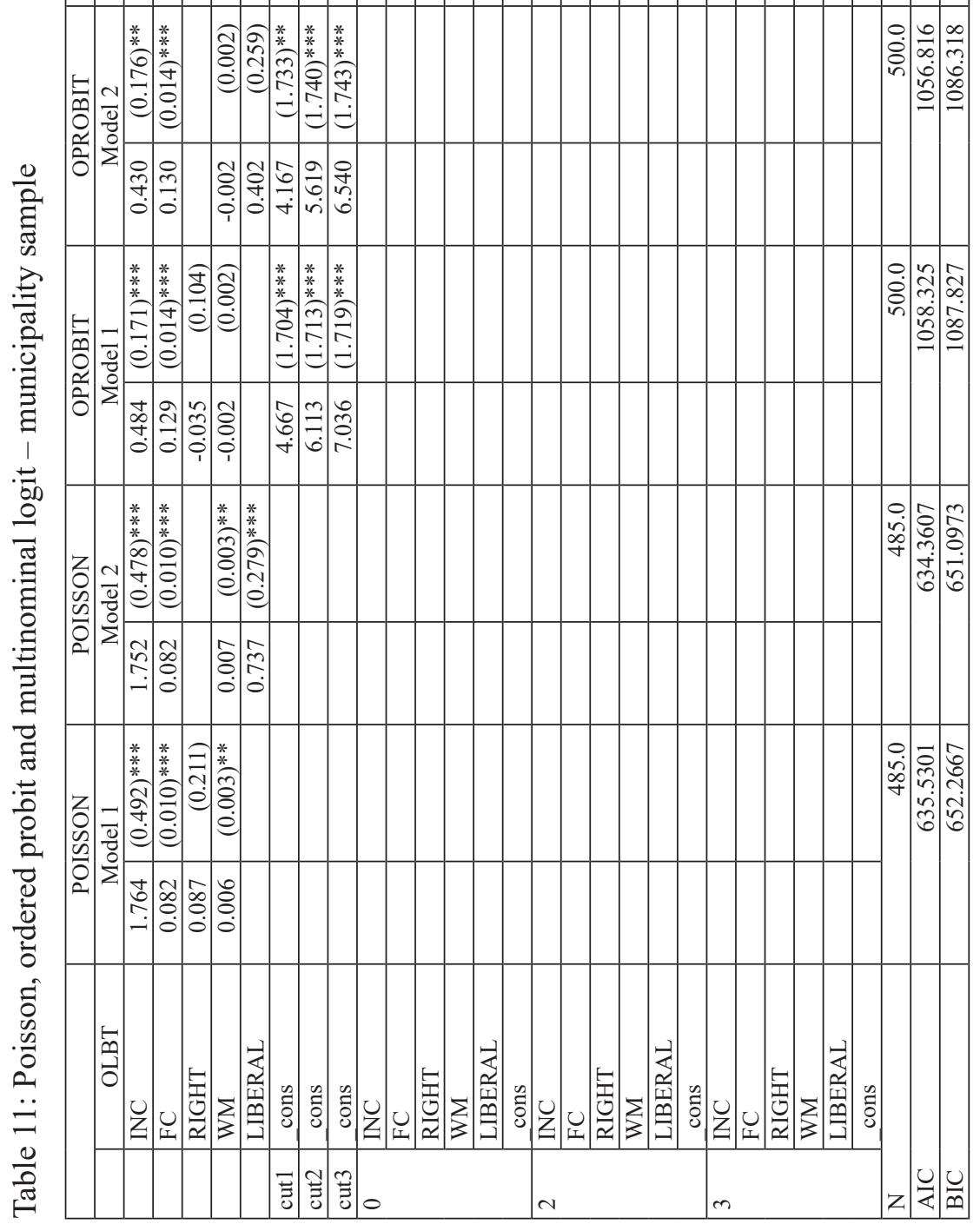

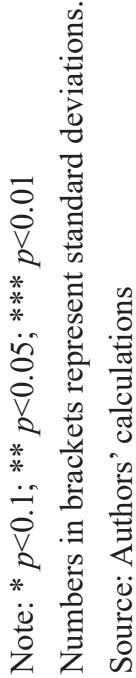

